\title{
Synthesis and thermotropic behavior of side chain polysiloxane bearing triphenylene moiety
}

\author{
T. Makowski ${ }^{*}$, T. Ganicz ${ }^{1}$,W. Zajaczkowski², W. Pisula², W. A. Stanczyk1 ${ }^{1}$ A. Tracz ${ }^{1}$ \\ ${ }^{1}$ Centre of Molecular and Macromolecular Studies, Polish Academy of Science, Sienkiewicza 112, 90-363 Lodz, Poland \\ ${ }^{2}$ Max Planck Institute for Polymer Research, Ackermannweg 10, 55128 Mainz, Germany
}

Received 19 November 2014; accepted in revised form 31 January 2015

\begin{abstract}
Side chain discotic polysiloxane with 2,3,6,7-tetrakis(hexyloxy)-10-methoxytriphenylene-11-undecanoate moieties is synthesized by hydrosilylation reaction. The phase behavior and thermooptical properties of the polysiloxane and the side chain precursor 2,3,6,7-tetrakis(hexyloxy)-10-methoxytriphenylene-11-undecanoate are examined by polarizing optical microscopy, thermooptical analysis, differential scanning calorimetry and wide angle X-ray scattering studies. A columnar planar alignment of LC in the layers has been determined. The pronounced alignment makes this polymer a promising material for application in optoelectronic devices. The differences in phase transitions and morphology between the triphenylene precursor and the discotic polysiloxane are discussed.
\end{abstract}

Keywords: thermal properties, discotic polysiloxane, atomic force microscope, polymer synthesis

\section{Introduction}

There has been an increasing interest in columnar discotics which involve $\pi$-conjugated systems [1-3]. They have been extensively studied as a result of their electro-optical and semiconducting properties as well as expected applications in organic field effect transistor devices (OFET) and solar cells [4-6]. They can undergo an easy macroscopic alignment and can be processed in a simple way [7-9]. Moreover, structural defects can be self-healed because of molecular fluctuations [10]. Flat, conjugated or fused discotic molecules possess unique features, making them important, potential material for one-dimensional charge carrier systems [11]. They are able to self-assemble into long-range 1D columnar arrays that can display liquid crystalline properties $[12,13]$. Discotic liquid crystals based on the triphenylene derivatives are particularly attractive as their chemistry is relatively accessible [14]. Semiconducting properties of low molecular triphenylenes have been already extensively studied and well proven [15-17].

On the other hand, liquid crystalline polymers, especially the ones incorporating calamitic moieties, belong to systems of wide interest. They combine the unique features of low molecular weight liquid crystals with increased thermal and mechanical stability of the mesophase and the possibility of macroscopic alignment, allowing to study the self-organization of the discotic mesogens, in order to investigate the oriented macroscopic structures [18]. Side chain polymers based on discotic mesogens have been much less explored and it concerns in particular systems based on flexible, linear polysiloxanes with triphenylene moieties. Only a limited number of star shaped oligomers $[12,19,20]$ and side chain systems [21-23] has been explored so far, although these polymers may also have an increased tendency to form columnar mesophases which might help to obtain thin layers with high molecular order.

\footnotetext{
${ }^{*}$ Corresponding author, e-mail: tomekmak@cbmm.lodz.pl (C) BME-PT
} 
In general, the attachment of a mesogenic structure to the flexible siloxane chain via a spacer maintains the liquid crystalline properties, but considerably reduces the transition temperatures with respect to the low molecular weight analogues [24]. Moreover, it was already proven that such polymers have a tendency to lower the crystal-mesophase temperature transition of discotic and calamitic mesophases [23]. In the past, preparation of side chain polysiloxanes with tripenylene mesogens involved complicated and low yield synthetic pathways. It refers in particular to synthesis of mono-substituted functionalized triphenylenes [22].

In this work, we present a simplified synthetic approach to an asymmetrically substituted triphenylene, functionalized with terminally unsaturated alkene moiety and the relevant side chain polysiloxane followed by phase transition studies of these novel systems.

\section{Experimental section \\ 2.1. Materials and methods \\ 2.1.1. Reagents}

Organometallic syntheses were carried out under argon with the exclusion of moisture. 1,2-dihexyloxybenzene, guiacol, anhydrous $\mathrm{FeCl}_{3}$, dicyclohexylcarbodiimide (DCC), N-N-dimethylaminopirydyne (DMAP), undecenoic acid all Aldrich Poland, poly (methylhydrosiloxane), 30cSt (an average molecular weight of $2100 \mathrm{~g} \cdot \mathrm{mol}^{-1}$. (ABCR Germany), $\mathrm{H}_{2} \mathrm{SO}_{4}$ conc. 98\%, ethanol $98 \%, \mathrm{CH}_{2} \mathrm{Cl}_{2}$, THF all POCh Poland, were used as supplied. Toluene (POCh Poland), used for hydrosilylation reaction, was dried by standard methods and stored over a sodium mirror [25]. Toluene, $\mathrm{CH} 2 \mathrm{Cl} 2$, THF and hexane (Aldrich/Fluka Poland, HPLC grade) used for column chromatography were used as supplied.

\subsubsection{Spectroscopy}

The ${ }^{1} \mathrm{H}-,{ }^{13} \mathrm{C}$ - and ${ }^{29} \mathrm{Si}-\mathrm{NMR}$ spectra were recorded in $\mathrm{CDCl}_{3}$ or toluene solutions with a Bruker AC 200 or a Bruker DRX 500 spectrometers. IR spectra were obtained with an ATI Mattson spectrometer for polymer solutions in sodium dried toluene.

\subsubsection{Molecular weight measurement}

Molecular weights were measured by gel-permeation chromatography (GPC) using a Waters system with Wyatt/Optilab 902 Interferometric Refractometer, analyses were performed on an LDC Analytical refracto Monitor IV instrument working with an RI detector and equipped with two SDV columns of the following parameters: $8 \times 300 \mathrm{~mm}, 5 \mu \mathrm{m}$ particle size, with $10^{4}$ and $100 \AA$ pore size. Toluene was used as an eluent at a flow rate of $0.7 \mathrm{~mL} / \mathrm{min}$. Molecular masses were calculated relative to polystyrene standards.

\subsubsection{Thermooptical analysis (TOA)}

Changes of the transmission of polarized light as a function of temperature were recorded and visualized using an author's software TOAPLOTS. Simultaneously the morphology of thin layers was observed under optical microscope. Morphology of samples was studied using Nikon Eclipse E400 Pol microscope equipped with polarizing filters and an analog SANYO VCC-3770P camera. The images were acquired using Leadtek TV Tuner WinFast PVR2. Heating and cooling of the samples at a controlled rate was accomplished using Mettler FP82 hot stage equipped with an FP90 controller and a photo detector.

\subsubsection{Differential scanning calorimetry (DSC)}

Differential scanning calorimetry (DSC) studies were performed using TA Instruments Q20 and DuPont DSC-910, calibrated with an indium standard at a rate of $5^{\circ} \mathrm{C} /$ min under nitrogen flow.

\subsubsection{Atomic force microscopy (AFM)}

Atomic force microscopy (AFM) images were recorded under ambient atmosphere, at room temperature using Nanoscope IIIa, MultiMode (Veeco, Santa Barbara, CA) microscope. The probes were commercially available rectangular silicon cantilevers (RTESP from Veeco) with nominal radius of curvature in the $10 \mathrm{~nm}$ range spring constant 20 $80 \mathrm{~N} / \mathrm{m}$, a resonance frequency lying in the 264$369 \mathrm{kHz}$. The images were recorded with the highest available sampling resolution, that is, $512 \times 512$ data points.

\subsubsection{D-WAXS}

The 2D wide angle X-ray scattering (2D-WAXS) measurements were performed by means of a solid anode X-ray tube (Siemens Kristalloflex X-ray source, copper anode X-ray tube operated at $35 \mathrm{kV}$ and $40 \mathrm{~mA}$ ), Osmic confocal MaxFlux optics, X-ray beam with pinhole collimation and a MAR345 image plate detector. The samples were prepared as a thin 
filament of $0.7 \mathrm{~mm}$ in diameter via filament extrusion in their LC phase. For the measurements, the samples were positioned perpendicular to the incident X-ray beam and scattering intensity was detected on a 2D image plate (MAR345) with a pixel size of $100 \mu \mathrm{m}(3450 \times 3450$ pixels $)$. Data analysis was performed using the Datasqueeze 3.0.0 software.

\subsection{Synthesis}

Synthesis of 2,3,6,7-tetra(hexyloxy)-10-methoxy11-hydroxy triphenylene (3) (Figure 1)

Functionalized triphenylenes (3) and (4) were prepared similar to the reported method [26].

$40 \mathrm{~g}(0.144 \mathrm{~mol})$ of 1,2-dihexyloxybenzene (1) and $35.75 \mathrm{~g}(0.288 \mathrm{~mol})$ of guiacol (2) were dissolved in $350 \mathrm{~mL}$. of concentrated aqueous $\mathrm{H}_{2} \mathrm{SO}_{4}(70 \%)$ in a 3 neck $2 \mathrm{~L}$ flask, equipped with an ice bath and mechanical stirrer and the reaction mixture was cooled down to $-13^{\circ} \mathrm{C} .93 .4 \mathrm{~g}(0.576 \mathrm{~mol})$ of anhydrous $\mathrm{FeCl}_{3}$ was slowly added at suitable rate, allowing to keep the temperature in the flask below $-10^{\circ} \mathrm{C}\left(2.5 \mathrm{hrs}\right.$.). After addition of $\mathrm{FeCl}_{3}$ the reaction mixture was stirred at room temperature for additional $5 \mathrm{hrs}$. Then $500 \mathrm{~g}$ of crushed ice was added and the reaction was stirred until ice melted completely. The crude product - dark green precipitate was filtered, washed three times with $200 \mathrm{~mL}$ of water, twice with $100 \mathrm{~mL}$ of ethanol and dried. The product was dissolved in $100 \mathrm{~mL}$ of $\mathrm{CH}_{2} \mathrm{Cl}_{2}$, precipitated again in $100 \mathrm{~mL}$ of ethanol, filtered and dried. The violet product was purified by fractional column chromatography ( $1 \mathrm{~m}$, silica gel $40 \mathrm{~A}$, eluents: hexane/THF $1: 1 \mathrm{v} / \mathrm{v})$, dried in vacuum $\left(60^{\circ} \mathrm{C}\right.$, $2 \mathrm{hrs}$ ), leaving $10.5 \mathrm{~g}$ of (3) (yield: $16 \%$ ).

${ }^{1} \mathrm{H}$ NMR: $\left(200 \mathrm{MHz}, \mathrm{CDCl}_{3}, \delta\right) \quad 0.85-0.95(\mathrm{~m}$, $\left.12 \mathrm{H}, \quad \mathrm{CH}_{3}-\left(\mathrm{CH}_{2}\right)_{5} \mathrm{O}\right), \quad 1.31-1.45(\mathrm{~m}, \quad 16 \mathrm{H}$, $\left.\mathrm{CH}_{3}\left(\mathrm{CH}_{2}\right)_{2}\left(\mathrm{CH}_{2}\right)_{3} \mathrm{O}\right), \quad 1.45-1.60 \quad(\mathrm{~m}, \quad 8 \mathrm{H}$, $\left.\mathrm{CH}_{3}\left(\mathrm{CH}_{2}\right)_{2} \mathrm{CH}_{2}\left(\mathrm{CH}_{2}\right)_{2} \mathrm{O}\right),{ }_{1.80-1.98}(\mathrm{~m}, 8 \mathrm{H}$, $\left.\mathrm{CH}_{3}\left(\mathrm{CH}_{2}\right)_{3} \mathrm{CH}_{2} \mathrm{CH}_{2} \mathrm{O}\right), 3.92$ (s, 3H, $\left.\mathrm{OCH}_{3}\right), 4.19-$ $4.31\left(\mathrm{~m}, 8 \mathrm{H}, \mathrm{CH}_{3}\left(\mathrm{CH}_{2}\right)_{4} \mathrm{CH}_{2} \mathrm{O}, 5.79-5.93(\mathrm{~s}, 1 \mathrm{H}\right.$, $\mathrm{OH}), 6.87\left(\mathrm{~d}, 2 \mathrm{H}\right.$, aromatic protons in $\mathrm{OH}$ and $\mathrm{OCH}_{3}$ substituted ring), 7.81-7.89 ( $\mathrm{m}, 4 \mathrm{H}$, aromatic in hexyloxy substituted rings), ${ }^{13} \mathrm{C}$ NMR: $(200 \mathrm{MHz}$, standard proton decoupling, $\left.\mathrm{CDCl}_{3}, \delta\right) 14.1\left(\mathrm{CH}_{3}\right)$, $22.6 \quad\left(\mathrm{CH}_{3} \mathrm{CH}_{2}\right), \quad 26.1 \quad\left(\mathrm{CH}_{3} \mathrm{CH}_{2} \mathrm{CH}_{2}\right), \quad 29.3$ $\left(\mathrm{CH}_{3}\left(\mathrm{CH}_{2}\right)_{2} \mathrm{CH}_{2}\right), 31.4 \quad\left(\mathrm{CH}_{3}\left(\mathrm{CH}_{2}\right)_{3} \mathrm{CH}_{2}\right), \quad 55.3$ $\left(\mathrm{OCH}_{3}\right), 68.9\left(\mathrm{OCH}_{2}\right), 104.6,104.8,104.9,105.1$ (aromatic carbons from hexyloxy substituted rings), 112.1, 112.2 (aromatic carbons from methoxy/ hydroxyl substituted rings), anal. calcd for $\mathrm{C}_{43} \mathrm{H}_{62} \mathrm{O}_{6}$ : C 76.22, H 9.26; found: C 75.93, H 9.16

Synthesis of 2,3,6,7-tetrakis(hexyloxy)-10methoxytriphenylene-11-undecenoate (4) (Figure 1) $10 \mathrm{~g}(0.015 \mathrm{~mol})$ of $(3), 2.7 \mathrm{~g}(0.015 \mathrm{~mol})$ of 10 undecenoic acid, $3 \mathrm{~g}(0.022 \mathrm{~mol})$ of DCC (dicyclohexylcarbodiimide) and $0.18 \mathrm{~g}$ of $\mathrm{N}, \mathrm{N}$-dimethylaminopyridine (DMAP) were dissolved in $150 \mathrm{ml}$ of $\mathrm{CH}_{2} \mathrm{Cl}_{2}$ and stirred at room temperature for $48 \mathrm{hrs}$. The reaction mixture was filtered and the precipitate was washed twice with $50 \mathrm{~mL}$ of $\mathrm{CH}_{2} \mathrm{Cl}_{2}$. The solvent was evaporated leaving white, crystalline product, which was purified by fractional column chromatography $(1 \mathrm{~m}$, silica gel $40 \mathrm{~A}$, eluents: $\mathrm{CH}_{2} \mathrm{Cl}_{2} /$ toluene $1: 2 \mathrm{v} / \mathrm{v}$ ) (yield: $3.7 \mathrm{~g}, 30 \%$ ). ${ }^{1} \mathrm{H}$ NMR: (200 MHz, $\left.\mathrm{C}_{6} \mathrm{D}_{6}, \delta\right)$ 0.75-0.97 (m, 12H, $\left.\mathrm{CH}_{3}-\left(\mathrm{CH}_{2}\right)_{5} \mathrm{O}\right), \quad 1.20-1.32 \quad(\mathrm{~m}, \quad 26 \mathrm{H}$, $\left.\mathrm{CH}_{3}\left(\mathrm{CH}_{2}\right)_{2}\left(\mathrm{CH}_{2}\right)_{3} \mathrm{O}+\mathrm{CH}=\mathrm{CH}\left(\mathrm{CH}_{2}\right)_{5}\left(\mathrm{CH}_{2}\right)_{3} \mathrm{COO}\right)$, 1.35-1.58 (m, 8H, $\left.\mathrm{CH}_{3}\left(\mathrm{CH}_{2}\right)_{2} \mathrm{CH}_{2}\left(\mathrm{CH}_{2}\right)_{2} \mathrm{O}\right), 1.72-$ $2.14\left(\mathrm{~m}, 8 \mathrm{H}, \mathrm{CH}_{3}\left(\mathrm{CH}_{2}\right)_{3} \mathrm{CH}_{2} \mathrm{CH}_{2} \mathrm{O}\right), 2.32-2.46(\mathrm{~m}$, $\left.2 \mathrm{H}, \mathrm{CH}=\mathrm{CH}\left(\mathrm{CH}_{2}\right)_{6} \mathrm{CH}_{2} \mathrm{CH}_{2} \mathrm{COO}\right), 2.51-2.74(\mathrm{~m}$, $\left.2 \mathrm{H}, \mathrm{CH}=\mathrm{CH}\left(\mathrm{CH}_{2}\right)_{7} \mathrm{CH}_{2} \mathrm{COO}\right), 3.93\left(\mathrm{~s}, 3 \mathrm{H}, \mathrm{OCH}_{3}\right)$, 4.13-4.30 (m, 8H, $\mathrm{CH}_{3}\left(\mathrm{CH}_{2}\right)_{4} \mathrm{CH}_{2} \mathrm{O}, 4.81-5.06$ (m, $\left.2 \mathrm{H}, \mathrm{CH}_{2}=\mathrm{CH}-\right)$, 5.71-5.99 (m, $\left.1 \mathrm{H}, \mathrm{CH}_{2}=\mathrm{CH}-\right)$, $7.31(\mathrm{~s}, 1 \mathrm{H}$, aromatic from undecenoic ester substituted ring), 7.77-7.88 ( $\mathrm{m}, 4 \mathrm{H}$, aromatic from hexyloxy substituted rings), 8.09 (s, $1 \mathrm{H}$, aromatic from methoxy substituted ring), ${ }^{13} \mathrm{C}$ NMR: $(200 \mathrm{MHz}$, standard proton decoupling, $\left.\mathrm{C}_{6} \mathrm{D}_{6}, \delta\right) 14.3\left(\mathrm{CH}_{3}\right)$, $23.1 \quad\left(\mathrm{CH}_{3} \mathbf{C H}_{2}\right), \quad 26.3 \quad\left(\mathrm{CH}_{3} \mathrm{CH}_{2} \mathbf{C H}_{2}\right), \quad 29.0$ $\left(\mathrm{CH}_{2}=\mathrm{CHCH}_{2} \mathbf{C H}_{2}\right), 29.1\left(\mathrm{CH}_{2}=\mathrm{CH}\left(\mathrm{CH}_{2}\right)_{2} \mathbf{C H}_{2}\right)$, $29.6 \quad\left(\mathrm{CH}_{2}=\mathrm{CH}\left(\mathrm{CH}_{2}\right)_{3} \mathrm{CH}_{2}\right), \quad 29.8$ $\left(\mathrm{CH}_{2}=\mathrm{CH}\left(\mathrm{CH}_{2}\right)_{4} \mathrm{CH}_{2}\right), 30.8\left(\mathrm{CH}_{3}\left(\mathrm{CH}_{2}\right)_{2} \mathrm{CH}_{2}\right), 30.9$ $\left(\mathrm{CH}_{3}\left(\mathrm{CH}_{2}\right)_{3} \mathrm{CH}_{2}\right), 31.1\left(\mathrm{CH}_{2}=\mathrm{CH}\left(\mathrm{CH}_{2}\right)_{5} \mathrm{CH}_{2}\right), 32.6$ $\left(\mathrm{CH}_{2}=\mathrm{CH}\left(\mathrm{CH}_{2}\right)_{6} \mathrm{CH}_{2}\right), 33.7\left(\mathrm{CH}_{2}=\mathrm{CHCH}_{2}\right), 33.8$ $\left(\mathrm{O}(\mathrm{O}) \mathrm{CCH}_{2}\right), 55.9\left(\mathrm{OCH}_{3}\right), 69.1\left(\mathrm{OCH}_{2}\right), 103.8$, 103.9, 104.1, 104.11 (aromatic carbons from hexyloxy substituted rings), 111.1, 111.2 (aromatic carbons from methoxy/undecenoic ester substituted ring), $114.6\left(\mathbf{C H}_{2}=\mathrm{CH}\right), 139.8\left(\mathrm{CH}_{2}=\mathbf{C H}\right)$, anal. calcd for $\mathrm{C}_{52} \mathrm{H}_{82} \mathrm{O}_{7}$ 77.10, H 9.59; found: C 77.20, H 9.40

\section{Synthesis of side chain discotic polysiloxane via} hydrosilylation of (4) with poly(methylhydrosiloxane) (5) (Figure 1) $2 \mathrm{~g}(2.38 \mathrm{mmol})$ of (4) and $128 \mathrm{mg}$ of poly(methylhydrosiloxane) $\left(2.14 \mathrm{mmol}\right.$ of $-\left[\mathrm{CH}_{3} \mathrm{Si}(\mathrm{H}) \mathrm{O}-\right]-$ monomeric units were dissolved in $20 \mathrm{ml}$ of dry 
toluene and stirred under argon. Platinum tetramethyldivinyldisiloxane (PTDD) complex in xylenes $\left(10^{-4} \mathrm{~mol} \mathrm{Pt} / \mathrm{mol} \mathrm{SiH}\right)$ was added and the reaction mixture was stirred at $60^{\circ} \mathrm{C}$. Reaction progress was followed by FTIR (disappearance of $\mathrm{Si}-\mathrm{H}$ absorption band at $2150 \mathrm{~cm}^{-1}$ ). After $24 \mathrm{hrs}$ the amount of unreacted $\mathrm{Si}-\mathrm{H}$ bonds was $\sim 11 \%$ and after $48 \mathrm{hrs}$ $6 \%$ was left. The reaction was continued until the total disappearance of the absorption at $2150 \mathrm{~cm}^{-1}$ (72 hrs). The solvent was removed in vacuum, leaving white solid. The product was purified by multiple precipitations from dichloromethane/methanol, filtration using PTFE $0.45 \mu \mathrm{m}$ microfilter and was dried in vacuum $\left(75^{\circ} \mathrm{C}, 1 \mathrm{mmHg}\right.$ ) (yield $1.23 \mathrm{~g}$, 58\%). ${ }^{1} \mathrm{H}$ NMR: (200 MHz, toluene-D, $\delta$ ) 0.04 (s, $\left.3 \mathrm{H}, \mathrm{SiCH}_{3}\right), 0.40-0.65$ (m, 2H, $\left.\mathrm{Si}-\mathrm{CH}_{2}\right), 0.76-0.98$ (m, $\left.12 \mathrm{H}, \mathrm{CH}_{3}-\left(\mathrm{CH}_{2}\right)_{5} \mathrm{O}\right), 1.22-1.38(\mathrm{~m}, 30 \mathrm{H}$, $\left.\mathrm{CH}_{3}\left(\mathrm{CH}_{2}\right)_{2}\left(\mathrm{CH}_{2}\right)_{3} \mathrm{O}+\mathrm{Si}-\mathrm{CH}_{2}\left(\mathrm{CH}_{2}\right)_{7}\left(\mathrm{CH}_{2}\right)_{2} \mathrm{COO}\right)$, 1.40-1.65 (m, 8H, $\left.\mathrm{CH}_{3}\left(\mathrm{CH}_{2}\right)_{2} \mathrm{CH}_{2}\left(\mathrm{CH}_{2}\right)_{2} \mathrm{O}\right), 1.80$ $2.21\left(\mathrm{~m}, 8 \mathrm{H}, \mathrm{CH}_{3}\left(\mathrm{CH}_{2}\right)_{3} \mathrm{CH}_{2} \mathrm{CH}_{2} \mathrm{O}\right), 2.64-2.70$ (m, $\left.2 \mathrm{H}, \mathrm{Si}-\left(\mathrm{CH}_{2}\right)_{8} \mathrm{CH}_{2} \mathrm{CH}_{2} \mathrm{COO}\right), 3.25-3.57(\mathrm{~m}, 2 \mathrm{H}$, $\left.\mathrm{Si}-\left(\mathrm{CH}_{2}\right)_{9} \mathrm{CH}_{2} \mathrm{COO}\right), 3.97$ (s, $\left.3 \mathrm{H}, \mathrm{OCH}_{3}\right), 4.18-4.35$ (m, $\left.8 \mathrm{H}, \mathrm{CH}_{3}\left(\mathrm{CH}_{2}\right)_{4} \mathrm{CH}_{2} \mathrm{O}\right), 6.82(\mathrm{~s}, 2 \mathrm{H}$, aromatic protons from undecanoate/ $\mathrm{OCH}_{3}$ substituted ring), 7.73-7.95 (m, 4H, aromatic from hexyloxy substituted rings), (Figure 1), ${ }^{13} \mathrm{C}$ NMR: (500 MHz, standard proton decoupling, $\left.\mathrm{C}_{6} \mathrm{D}_{6}, \delta\right) 0.38\left(\mathrm{CH}_{3} \mathrm{Si}\right), 14.2$ $\left(\mathrm{CH}_{3}\right), 17.4\left(\mathrm{SiCH}_{2}\right), 20.6\left(\mathrm{SiCH}_{2} \mathrm{CH}_{2}\right), 20.8$ $\left(\mathrm{Si}\left(\mathrm{CH}_{2}\right)_{2} \mathbf{C H}_{2}\right), 22.9\left(\mathrm{CH}_{3} \mathbf{C H}_{2}\right), 25.1\left(\mathrm{Si}\left(\mathrm{CH}_{2}\right)_{3} \mathbf{C H}_{2}\right)$, $25.9\left(\mathrm{CH}_{3} \mathrm{CH}_{2} \mathrm{CH}_{2}\right), 29.4\left(\mathrm{Si}\left(\mathrm{CH}_{2}\right)_{4} \mathrm{CH}_{2}\right), 30.8$ $\left(\mathrm{CH}_{3}\left(\mathrm{CH}_{2}\right)_{2} \mathbf{C H}_{2}\right), \quad 30.9 \quad\left(\mathrm{Si}\left(\mathrm{CH}_{2}\right)_{5} \mathbf{C H}_{2}\right), \quad 31.0$ $\left(\mathrm{Si}\left(\mathrm{CH}_{2}\right)_{6} \mathrm{CH}_{2}\right), \quad 31.1 \quad\left(\mathrm{Si}\left(\mathrm{CH}_{2}\right)_{7} \mathrm{CH}_{2}\right), \quad 32.6$ $\left(\mathrm{CH}_{3}\left(\mathrm{CH}_{2}\right)_{3} \mathbf{C H}_{2}\right), \quad 32.9 \quad\left(\mathrm{Si}\left(\mathrm{CH}_{2}\right)_{8} \mathbf{C H}_{2}\right), \quad 33.8$ $\left(\mathrm{O}(\mathrm{O}) \mathrm{CCH}_{2}\right), 55.7\left(\mathrm{OCH}_{3}\right), 68.9\left(\mathrm{OCH}_{2}\right), 103.3$,
103.4, 103.6, 103.9 (aromatic carbons from hexyloxy substituted rings), 111.0, 111.1 (aromatic carbons from undecanoate/ $\mathrm{OCH}_{3}$ substituted ring), ${ }^{29} \mathrm{Si} \mathrm{NMR}$ : (500 Mhz, INEPT, $\mathrm{C}_{6} \mathrm{D}_{3} \delta$ ): -5 (MeSiO), GPC: $M_{\mathrm{n}}=36800, M_{\mathrm{w}}=56200$.

\section{Results and discussion}

\subsection{Synthesis}

The easiest and most frequently used method in polymer chemistry to attach side chains to polysiloxanes is hydrosilylation reaction, in which terminal alkenes are silylated with polymers bearing $\mathrm{Si}-\mathrm{H}$ moieties [27, 28]. However, the synthetic bottleneck was the preparation of unsymmetrically substituted conjugated aromatic structures (3) possessing one single substituent with terminal alkene moiety (4), which can be later attached to polysiloxanes as a side chain via hydrosilylation reaction. We have applied a modified methodology, described for synthesis of similar triphenylenes, bearing one reactive group, which served as monomers for the preparation of side chain discotic polyacetylenes (Figure 1).

It involved cyclotrimerization of a mixture of 1,2dihexyloxybenzene and guiacol leading to 'one-pot' formation of the triphenylene moiety (3) (Figure 1). The reaction was straightforward, however, required careful purification using several cycles of column chromatography in order to separate undesired side products such as perhexyloxy triphenylenes. This procedure led to a lower reaction yield.

In the second step (Figure 1) the esterification of (3) with undecenoic acid was carried out, catalyzed by DMAP in the presence of DCC. Again, the most

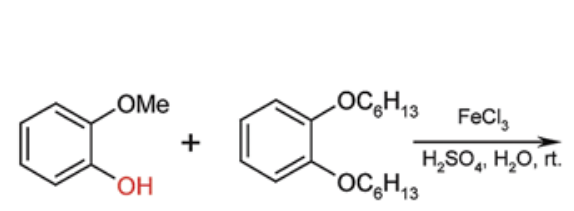

(1)

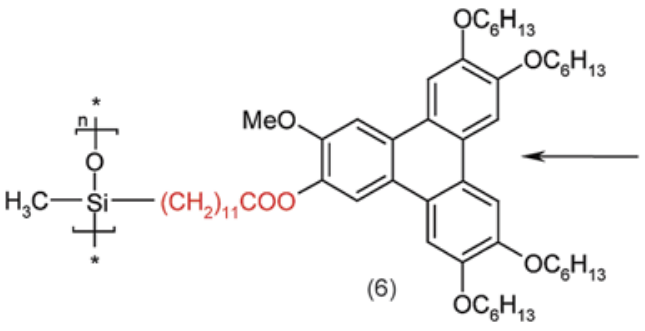

(2)

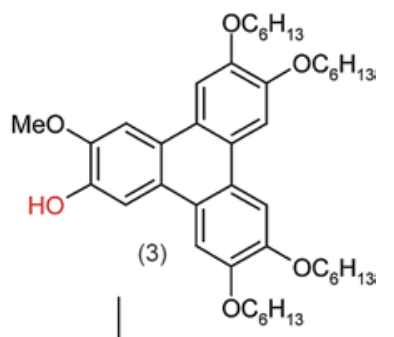

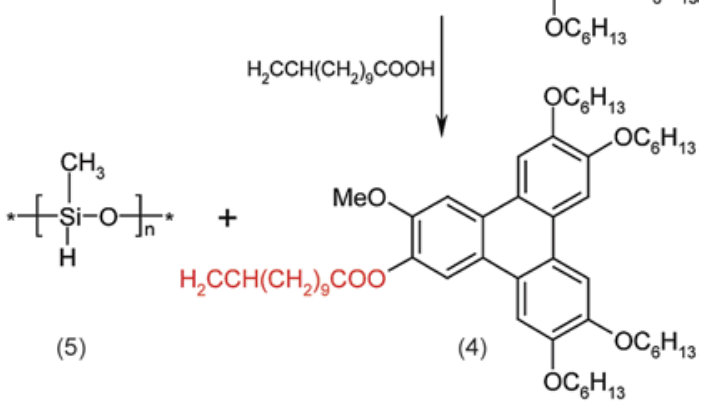

Figure 1. Synthesis of unsymmetric triphenylene and the relevant discotic side chain polysiloxane 
difficult part of the process was purification of the ester (4). The attachment of the side triphenylene groups to the polysiloxane was performed in typical hydrosilylation conditions (Figure 1) in toluene using Karstedt's catalyst at $60-80^{\circ} \mathrm{C}$.

The conversion of $90 \%$ after $24 \mathrm{hrs}$ (as proved by disappearance of $\mathrm{Si}-\mathrm{H}$ signal at $2100 \mathrm{~cm}^{-1}$ in FTIR) was rather typical for hydrosilylation of alkenes, bearing bulky substituents, by polysiloxanes [26, 27]. The reaction continued for further $48 \mathrm{hrs}$ led to final anchoring of $94 \%$ of unsaturated triphenylene ester. Although the final product (6) contained $6 \%$ of the unreacted $\mathrm{Si}-\mathrm{H}$ moieties, they were hydrolytically stable and we did not observe the effect of crosslinking by $\mathrm{Si}-\mathrm{H}$ hydrolysis and condensation even if the samples were heated up to $150^{\circ} \mathrm{C}$ and washed with water.

\subsection{Phase behavior studies}

Phase transition studies were carried out for triphenylene (4) and the discotic polymer (6) (Figure 1). All measurements were made by heating and cooling at the same rate of $5^{\circ} \mathrm{C} / \mathrm{min}$. The DSC heating scan (Figure 2a) reveals a phase transition temperature from the crystalline $(\mathrm{Cr})$ to the liquid crystalline (LC) phase at $68^{\circ} \mathrm{C}$ for (4) and $67^{\circ} \mathrm{C}$ for (6). The temperature difference, which accompanies this transition for (4) and (6) is $\Delta T=1{ }^{\circ} \mathrm{C}$ and a corresponding small change in enthalpy is observed $(\Delta H=0.6 \mathrm{~J} / \mathrm{g})$. Transition to the isotropic phase (Iso) occurs at the temperature of $99^{\circ} \mathrm{C}$ and is identical for both monomer (4) and polymer (6).

Upon cooling at the rate of $5^{\circ} \mathrm{C} / \mathrm{min}$, phase transitions from Iso to LC for both monomer (4) and poly-

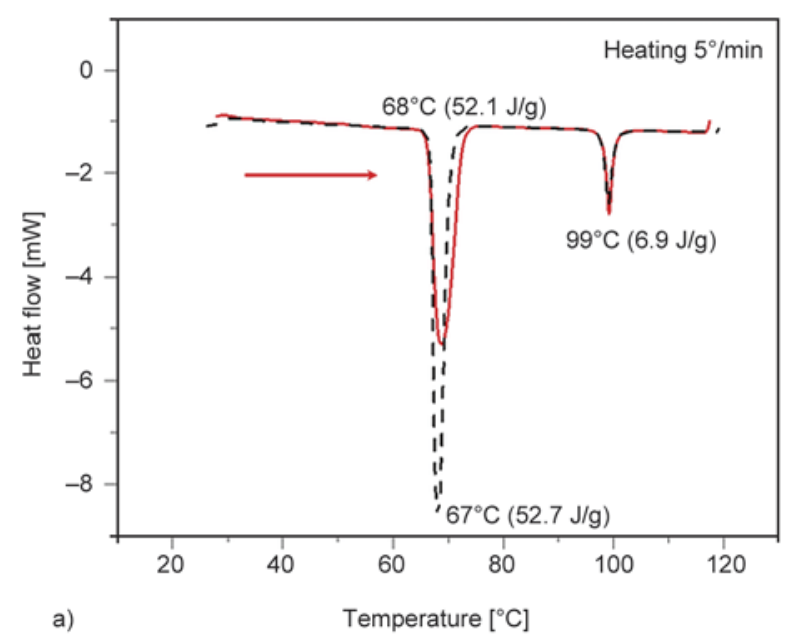

mer (6) occurs at $96^{\circ} \mathrm{C}$ (lack of a supercooling) and is accompanied by a enthalpy change $\Delta H=6.9 \mathrm{~J} / \mathrm{g}$ (Figure 2b). On the other hand, a small temperature difference of $\Delta T=1{ }^{\circ} \mathrm{C}$ between (4) and (6) is observed (Figure $2 \mathrm{~b}$ ) for the transition from the LC to $\mathrm{Cr}$ phase with $52^{\circ} \mathrm{C}$ for (4) and $51^{\circ} \mathrm{C}$ for $(6)$.

In addition to measurements obtained from differential scanning calorimetry (DSC) analysis, the phase transitions of (4) and (6) were independently studied by means of thermooptical analysis (TOA). The TOA experiments rely on the registration of intensity of polarized light and change of texture with temperature [23, 29]. Changes of the transmission of polarized light as function of temperature were recorded. Simultaneously, the morphology of layers was observed under optical microscope. TOA measurements were done for drop-cast films on a glass substrate. During measurements the layers were exposed to air without using a cover. The changes of the light intensity transmitted through the layers of (4) upon heating at a rate of $5^{\circ} \mathrm{C} / \mathrm{min}$ are shown in Figure 3. Upon heating of (4) the intensity of the transmitted light increases sharply at $67^{\circ} \mathrm{C}$ and accompanies the $\mathrm{Cr}-\mathrm{LC}$ transition, which can be attributed to the formation of mesomorphic state (LC) [30, 31] (Figure 3, image 1, 2). A fast decrease in intensity is observed at $98^{\circ} \mathrm{C}$, when the clearing temperature is reached (Figure 3, image 4)

The observed phase transitions were accompanied by the respective changes in the intensity of polarized light passing through the layer (Figure 3b). In order to measure precisely the temperatures, at which the phase transition occurred, the plot of $\mathrm{d} I / \mathrm{d} T$ is

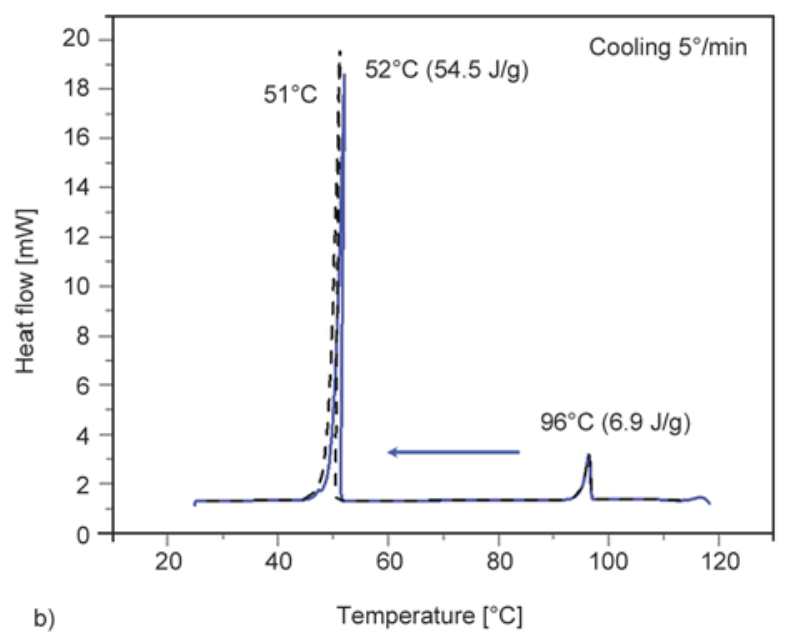

Figure 2. DSC thermogram: a) heating: red, continuous curve (4); black, dashed curve (6), b) cooling: blue, continuous curve (4); black, dashed curve (6) 

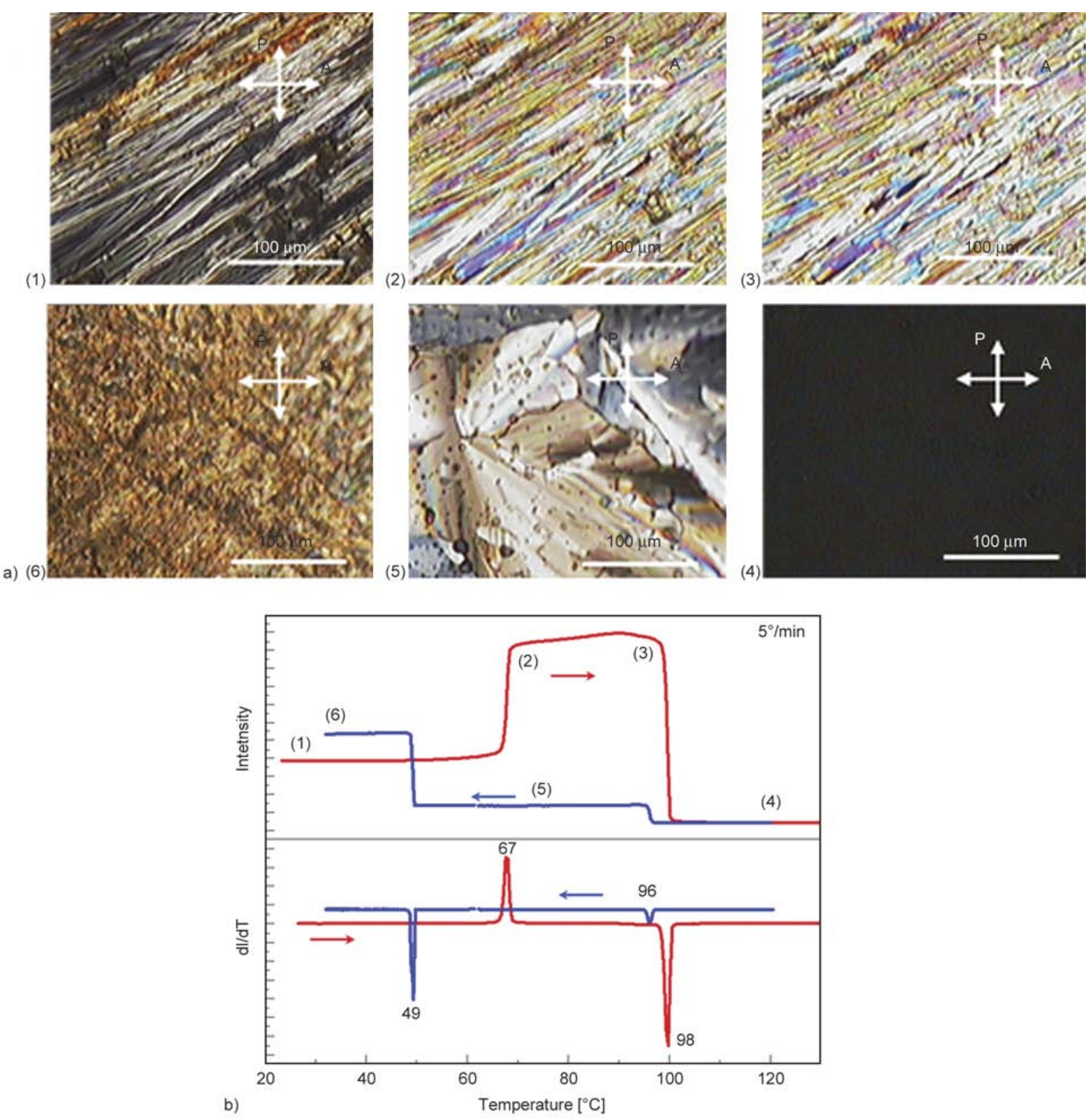

Figure 3. a) Images of textures of (4) from POM, b) TOA of (4): red curve corresponds to heating and blue curve to cooling process

presented. On cooling, the intensity increased at the temperature of $96^{\circ} \mathrm{C}$ (see Figure 3, blue curve $\mathrm{d} I / \mathrm{d} T$, image 4) due to formation of a fan structure by (4), which is characteristic for discotic liquid crystals [32]. In image 6 of Figure $3 a$ the transition to the crystalline phase occurring at $49^{\circ} \mathrm{C}$ is evident. The results from TOA for the triphenylene (4) correlate very well with the data obtained from the differential scanning calorimetry (DSC).

TOA analysis of polymer (6) points that on heating of the layer the $\mathrm{Cr}-\mathrm{LC}$ transition is observed changing the orientation of molecules [33]. This results in an increase in light intensity passing through the layer (red curve Figure 4a, image 1 and 2) at $58^{\circ} \mathrm{C}$. Further heating causes a complete reorientation of the molecules in the layer and the transition to the mesophase (LC) (image 3) at $67^{\circ} \mathrm{C}$. Rapid decline in light intensity occurs at a temperature of $98^{\circ} \mathrm{C}$ and the transition to the isotropic liquid is observed (image 4). On the other hand, on cooling from the isotropic liquid, the intensity change of light passing through the layer of (6) occurs only at the temperature of $48^{\circ} \mathrm{C}$, corresponding very well with results from DSC, indicating crystallization (image 6). The results obtained from TOA and DSC apparently differ from each other. As one can see from the texture 
(1)
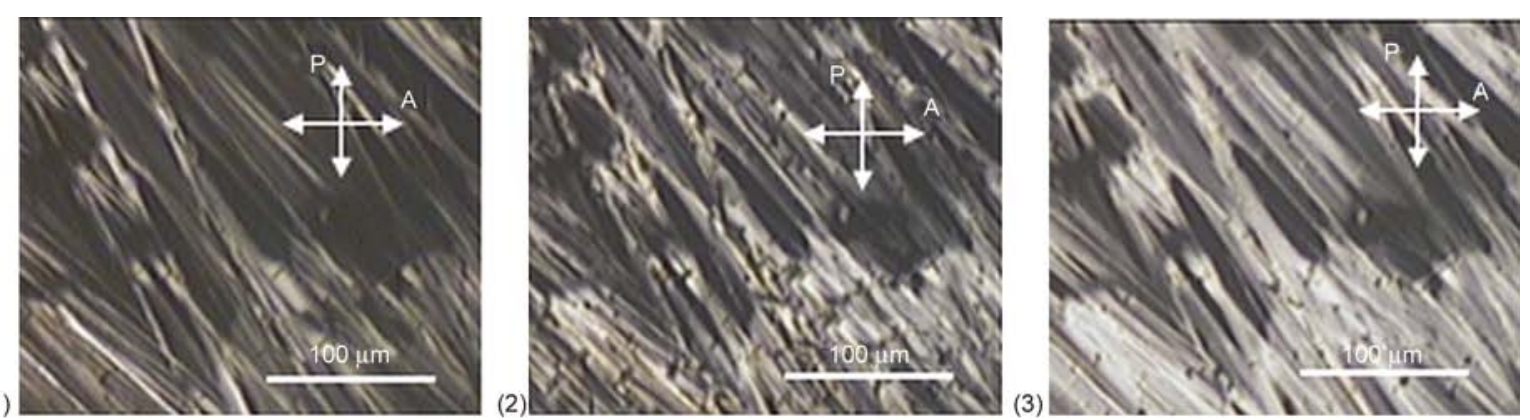

a)
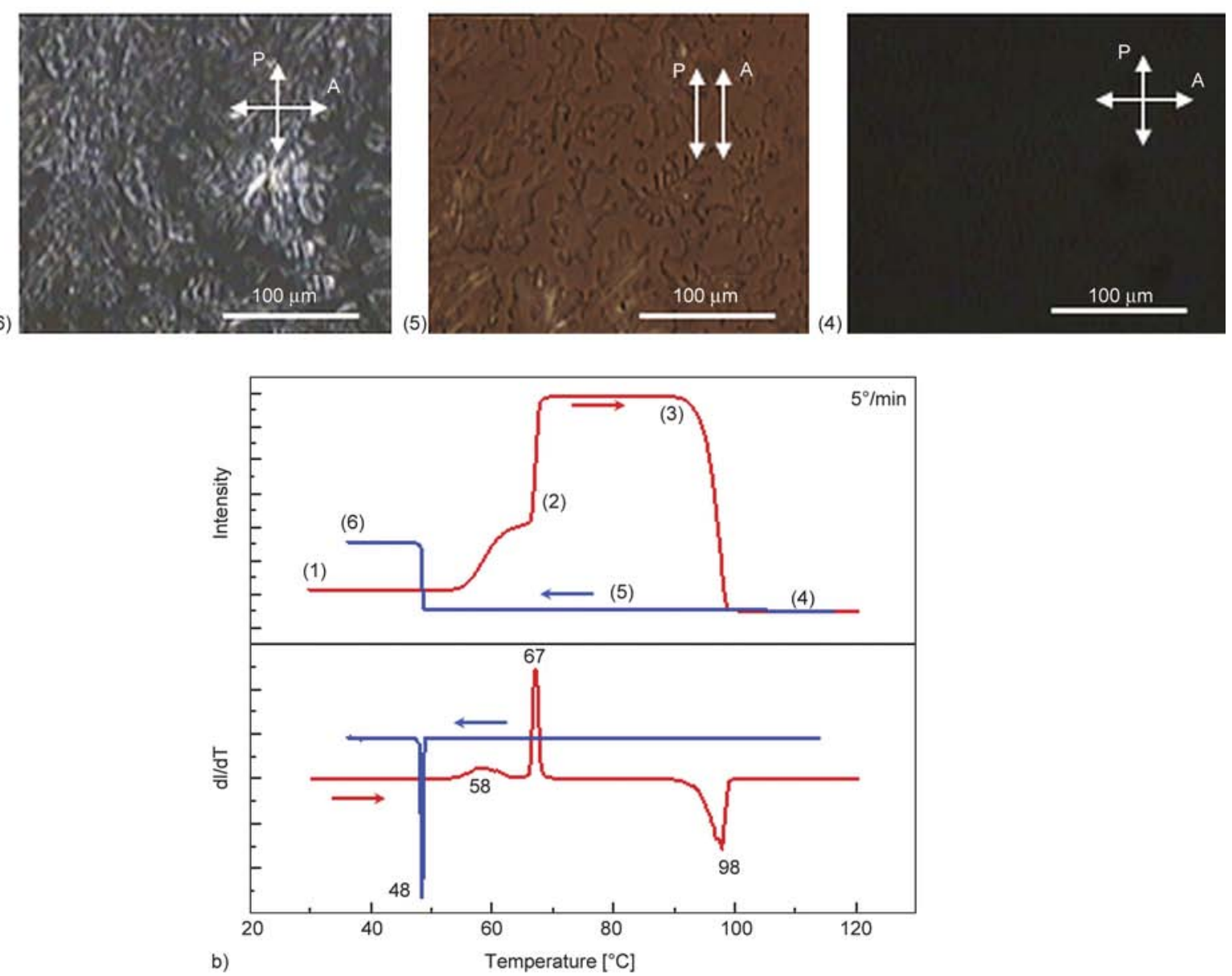

Figure 4. a) Images of textures of polymer (6) from POM, b) TOA of (6): red curve corresponds heating and blue curve to cooling process. Heating and cooling rates are $5^{\circ} \mathrm{C} / \mathrm{min}$.

recorded at $82^{\circ} \mathrm{C}$ (image 5) the $\mathrm{LC}$ transition is missing. On cooling from the isotropic phase $\left(\right.$ at $96^{\circ} \mathrm{C}-$ DSC) no change in the light intensity occurs in TOA (Figure $4 b$ ). The reason is most probably the formation of a homeotropic arrangement of the triphenylene molecules on the surface. In this organization, the molecules are face-on arranged on the surface with their columnar axis perpendicular to the substrate. This leads to the lack of birefringence in polarized light for typically a dendritic morphology of the LC phase [34-36]. We observed in TOA characteristic textures for this type arrangement [21] (Figure 4 - image 5) indicating a strong interaction with the substrate (Figure $4 b$ ).
For each layer (4 and 6) the morphology surface was analyzed using atomic force microscopy (AFM) (Figure 5). Thickness of each mono-layer (Figure 5b) of ca. $1.8 \mathrm{~nm}$ (corresponding to the thickness of a single sheet of columns) is in a reasonable agreement with earlier measurements performed on layers of similar triphenylenes [22] forming columnar structures. Additionally, this value is in accordance with the intercolumnar distance found for the bulk organization by X-ray scattering (Figure 7). All surface morphology studies were performed at $25^{\circ} \mathrm{C}$ for ascast samples. Analysis of the surface of polymer (6) was performed after the first heating cycle to a temperature of $120^{\circ} \mathrm{C}$. Observed morphologies of poly- 

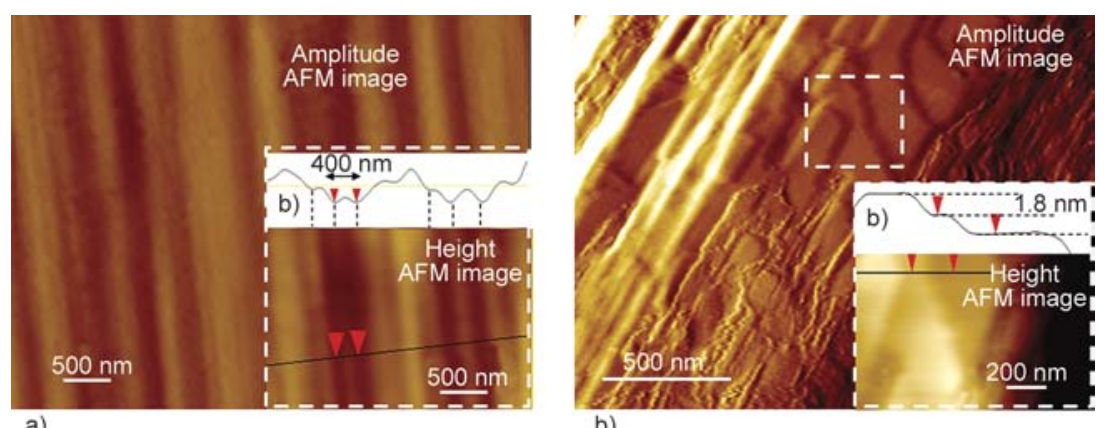

b)

Figure 5. AFM images: a) (4) amplitude image showing periodic structure, b) (6) amplitude image with a thickness of a single monolayer

mer liquid crystal (6), from AFM, shows the formation of regular patterns where the distances between interdigitated multilayer polymer chains are $15 \mathrm{~nm}$. (Figure 6) [37, 38].

The thermotropic behavior of (4) and (6) in bulk was studied by two-dimensional X-ray wide-angle scattering (2D-WAXS). The samples were prepared by fiber extrusion to induce macroscopic alignment in the specimen and were placed for the measurement vertically towards the $2 \mathrm{D}$ detector. In the LC phase both compounds self-assemble in identical characteristic structures (Figure 7b, 7d) [39]. The columnar stacks are oriented along the fiber direction as evident from the small-angle equatorial reflections. From the position of these scattering intensities the intercolumnar arrangement is determined of a slightly oblique with dissimilar unit cell parameters $a=$ $2.29 \mathrm{~nm}$ and $b=2.08 \mathrm{~nm}$ for (4) and $a=2.31 \mathrm{~nm}$ and $b=2.10 \mathrm{~nm}$ for (6). The disc-shaped triphenylenes pack in an orthogonal fashion in these stacks with a $\pi$-stacking distance of $0.36 \mathrm{~nm}$ in both cases as derived from the meridional wide-angle reflections (Figure 7f). Cooling back the samples to their crystalline phase, the organization changes into

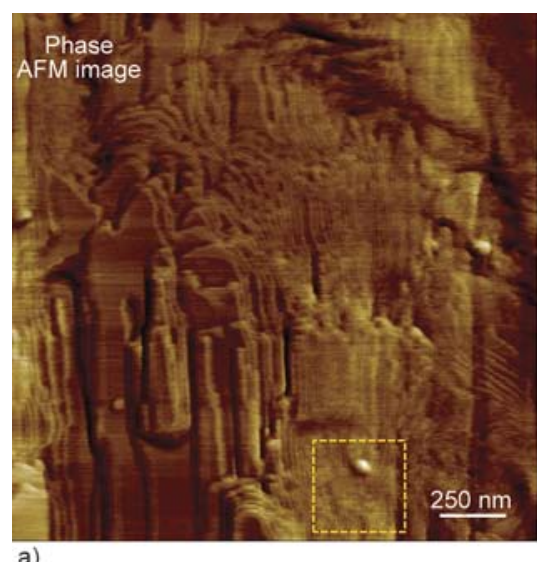

a) a herringbone structure with tilted molecules within the columnar structures (Figure 7a, 7c). The location of the off-meridional reflections with the maximum intensity indicates a similar tilting angle of ca $35^{\circ}$ for both compounds (Figure 7e). Due to the high number of reflections, the intercolumnar distance cannot be determined precisely from the data set. However, the comparison of the equatorial reflection suggests also a similar unit cell for (4) and (6) in the crystalline phase. In conclusion of the structural analysis, the introduction of the triphenylene as a side chain moiety of a polysiloxane does not affect the supramolecular bulk organization of the polycyclic aromatic hydrocarbon disc. The driving force for the self-assembly are $\pi$-stacking interactions, while the polysiloxane chain plays a minor role for the bulk structure. It can be assumed that the polysiloxane is arranged in the periphery of the stacks connecting molecules packed in the same column.

\section{Conclusions}

The synthetic pathway involved the known hydrosilylation process [22] for preparation of a novel system with hexyloxy modified triphenylene anchored

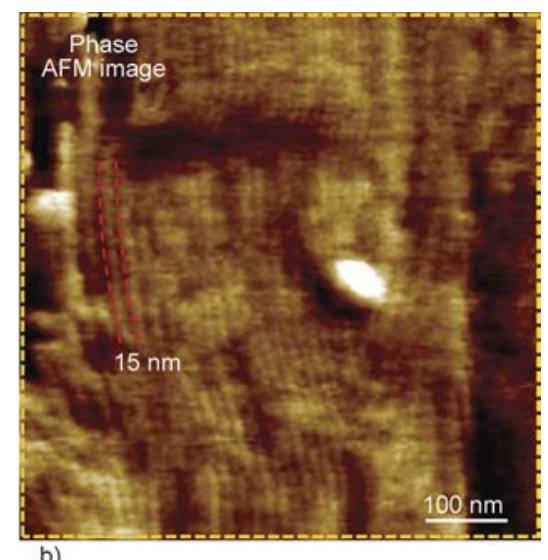

b)

Figure 6. AFM phase images of polymer (6); a) phase image for a $1 \times 1 \mu \mathrm{m}^{2}$ area, b) zoom of yellow square from a) showing $15 \mathrm{~nm}$ regular patterns 

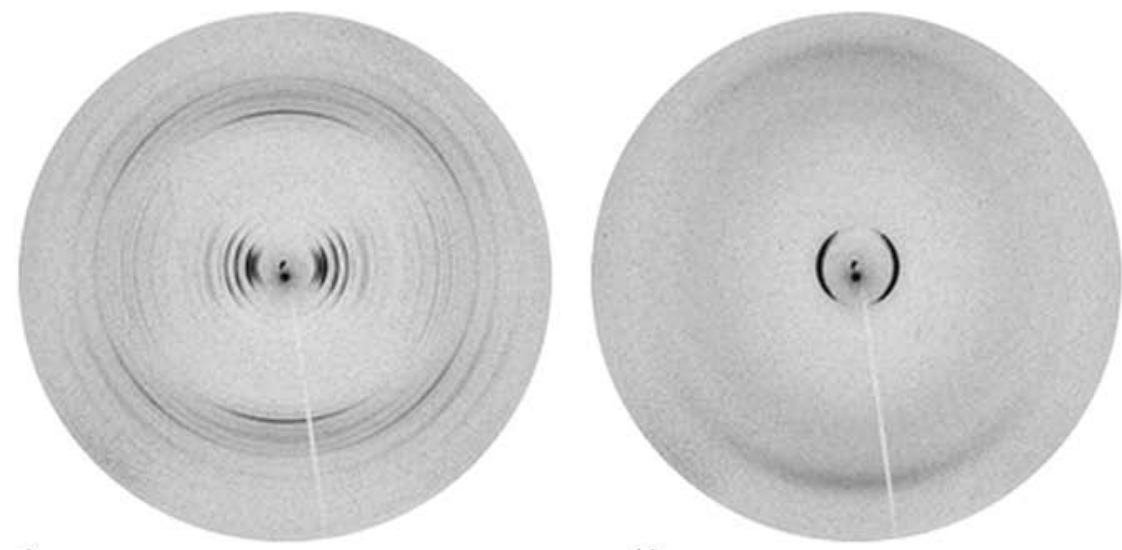

a)

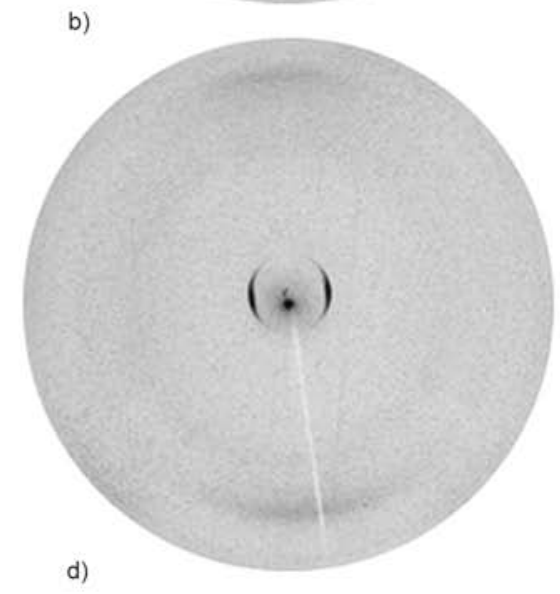

c)
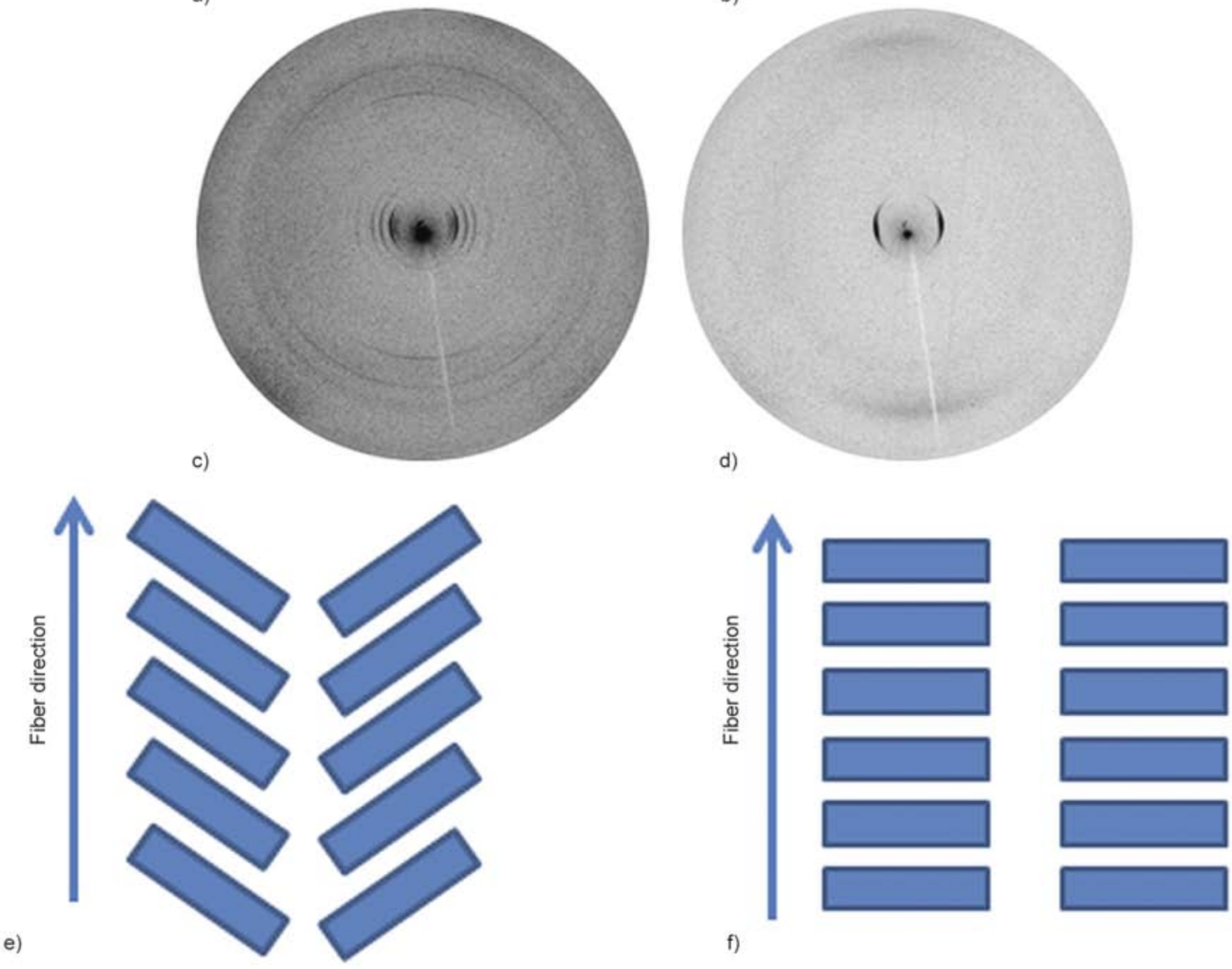

Figure 7. 2D-WAXS recorded at 30 and $80^{\circ} \mathrm{C}$ of a) and b) (4), c) and d) (6). Schematic illustration for the organization in e) crystalline and f) liquid crystalline phase.

on low molecular weight polysiloxane $\left(2100 \mathrm{~g} \cdot \mathrm{mol}^{-1}\right)$ via undecanoate flexible spacer. Transition temperatures determined by TOA correspond to those from DSC. Therefore, TOA can be considered as a very efficient and complementary tool for studies of phase transitions of some discotic systems. Moreover, smaller amount of materials (thickness layers smaller than $1 \mu \mathrm{m}$ can be analysed) is required for TOA experiments. Attachment of modified triphenylene moieties to polysiloxane via flexible spacer allows for self-organization of both side chain discotics and polymer skeleton. The spacer effectively decouples the motions of triphenylene side groups from the main polymer chain. Thus, the columnar ordering of side groups is still present. The attachment of triphenylene derivatives does not affect significantly the kinetics of self-organization (crystallization) in comparison to the plain discotic precursor, but provides higher thermal stability, characteristic of polymers. The onset temperature increases from $352.24^{\circ} \mathrm{C} \mathrm{(4)} \mathrm{to} 395.04^{\circ} \mathrm{C}$ for polymer system (6) and the respective decomposition rate decreases from 
$9.16 \% \cdot \mathrm{min} /{ }^{\circ} \mathrm{C}(4)$ to $6.59 \% \cdot \mathrm{min} /{ }^{\circ} \mathrm{C}(6)$. A good solubility in non-polar solvents is also assured by the presence of siloxane chain.

\section{Acknowledgements}

T.G., T.M and W.A.S. wish to thank Centre of Molecular and Macromolecular Studies for financial support within the statutory research program. W.Z. gratefully acknowledges the ERC Advanced Grant NANOGRAPH (AdG2010-267160).

\section{References}

[1] Laschat S., Baro A., Steinke N., Giesselmann F., Hägele C., Scalia G., Judele R., Kapatsina E., Sauer S., Schreivogel A., Tosoni M.: Discotic liquid crystals: From tailor-made synthesis to plastic electronics. Angewandte Chemie International Edition, 46, 4832-4887 (2007).

DOI: $10.1002 /$ anie. 200604203

[2] Pisula W., Zorn M., Chang J. Y., Müllen K., Zentel R.: Liquid crystalline ordering and charge transport in semiconducting materials. Macromolecular Rapid Communications, 30, 1179-1202 (2009).

DOI: $10.1002 /$ marc. 200900251

[3] Sergeyev S., Pisula W., Geerts Y. H.: Discotic liquid crystals: A new generation of organic semiconductors. Chemical Society Reviews, 36, 1902-1929 (2007). DOI: $10.1039 / \mathrm{B} 417320 \mathrm{C}$

[4] Wong W. W. H., Singh T. B., Vak D., Pisula W., Yan C., Feng X., Williams E. L., Chan K. L., Mao Q., Jones D. J., Ma C-Q., Müllen K., Bäuerle P., Holmes A. B.: Solution processable fluorenyl hexa-peri-hexabenzocoronenes in organic field-effect transistors and solar cells. Advanced Functional Materials, 20, 927-938 (2010).

DOI: $10.1002 / \mathrm{adfm} .200901827$

[5] Wong W. W. H., Ma C-Q., Pisula W., Yan C., Feng X., Jones D. J., Müllen K., Janssen R. A. J., Bäuerle P., Holmes A. B.: Self-assembling thiophene dendrimers with a hexa-peri-hexabenzocoronene core-synthesis, characterization and performance in bulk heterojunction solar cells. Chemistry of Materials, 22, 457-466 (2009). DOI: $10.1021 / \mathrm{cm} 903272 \mathrm{y}$

[6] Tsao H. N., Pisula W., Liu Z., Osikowicz W., Salaneck W. R., Müllen K.: From ambi- to unipolar behavior in discotic dye field-effect transistors. Advanced Materials, 20, 2715-2719 (2008). DOI: 10.1002/adma.200702992

[7] Tracz A., Makowski T., Masirek S., Pisula W., Geerts Y. H.: Macroscopically aligned films of discotic phthalocyanine by zone casting. Nanotechnology, 18, 485303/1485303/5 (2007).

DOI: $\underline{10.1088 / 0957-4484 / 18 / 48 / 485303}$
[8] Kastler M., Pisula W., Laquai F., Kumar A., Davies R. J., Baluschev S., Garcia-Gutiérrez M. C., Wasserfallen D., Butt H. J., Riekel C., Wegner G., Müllen K.: Organization of charge-carrier pathways for organic electronics. Advanced Materials, 18, 2255-2259 (2006). DOI: $10.1002 /$ adma.200601177

[9] Miskiewicz P., Rybak A., Jung J. Y., Glowacki I., Maniukiewicz W., Tracz A., Pfleger J., Ulanski J., Müllen K.: One-step method of producing uniaxially oriented layers of organic discotic molecules for field-effect transistors. Nonlinear Optics, Quantum Optics, 37, 207218 (2007).

[10] Pisula W., Tomović Ž., Watson M. D., Müllen K., Kussmann J., Ochsenfeld C., Metzroth T., Gauss J.: Helical packing of discotic hexaphenyl hexa-peri-hexabenzocoronenes: Theory and experiment. The Journal of Physical Chemistry B, 111, 7481-7487 (2007).

DOI: $10.1021 / j p 071167 \mathrm{i}$

[11] Warman J. M., Piris J., Pisula W., Kastler M., Wasserfallen D., Müllen K.: Charge recombination via intercolumnar electron tunneling through the lipid-like mantle of discotic hexa-alkyl-hexa-peri-hexabenzocoronenes. Journal of the American Chemical Society, 127, 14257-14262 (2005).

DOI: $10.1021 / \mathrm{ja} 0532250$

[12] Hoang M. H., Nguyen D. N., Choi D. H.: $\pi$-extended conjugated semiconducting molecules based on triphenylene. Advances in Natural Sciences: Nanoscience and Nanotechnology, 2, 035002/1-035002/8 (2011). DOI: $10.1088 / 2043-6262 / 2 / 3 / 035002$

[13] van de Craats A. M., Warman J. M., de Haas M. P., Adam D., Simmerer J., Haarer D., Schuhmacher P.: The mobility of charge carriers in all four phases of the columnar discotic material hexakis(hexylthio)triphenylene: Combined TOF and PR-TRMC results. Advanced Materials, 8, 823-826 (1996).

DOI: $10.1002 / \mathrm{adma} .19960081012$

[14] Cammidge A. N., Bushby R. J.: Synthesis and structural features of discotic liquid crystals. Wiley, Weinheim (1998).

[15] Adam D., Closs F., Frey T., Funhoff D., Haarer D., Ringsdorf H., Schuhmacher P., Siemensmeyer K.: Transient photoconductivity in a discotic liquid crystal. Physical Review Letters, 70, 457-461 (1993). DOI: 10.1103/PhysRevLett.70.457

[16] Cammidge A. N., Gopee H.: Structural factors controlling the transition between columnar-hexagonal and helical mesophase in triphenylene liquid crystals. Journal of Materials Chemistry, 11, 2773-2783 (2001). DOI: 10.1039/B103450M

[17] Xiao B., Liu Z-J., Wang B-Q., Hu P., Redshaw C., Zhao K-Q.: Synthesis of triphenylene discotic liquid crystals possessing nine alkyl chains: Influence of molecular symmetry and chain length on mesomorphism. Molecular Crystals and Liquid Crystals, 577, 25-35 (2013).

DOI: $\underline{10.1080 / 15421406.2013 .781489}$ 
[18] Dubois J-C., Barny P. L., Mouzac M., Noel C.: Behaviour and properties of side group thermotropic liquid crystal polymers. in 'Handbook of liquid crystals' (eds.: Demus D., Goodby J., Gray G. W., Spiess H. W., Vill V.) Wiley-VCH, Weinheim, Vol 3, 207-228 (1998).

[19] Zelcer A., Donnio B., Bourgogne C., Cukiernik F. D., Guillon D.: Mesomorphism of hybrid siloxane-triphenylene star-shaped oligomers. Chemistry of Materials, 19, 1992-2006 (2007).

DOI: $10.1021 / \mathrm{cm} 062949 \mathrm{~b}$

[20] Han B., Hu P., Wang B-Q., Redshaw C., Zhao K-Q.: Triphenylene discotic liquid crystal trimers synthesized by $\mathrm{Co}_{2}(\mathrm{CO})_{8}$-catalyzed terminal alkyne $[2+2+2]$ cycloaddition. Beilstein Journal of Organic Chemistry, 9, 2852-2861 (2013). DOI: $10.3762 /$ bjoc. 9.321

[21] Hüser B., Pakula T., Spiess H W.: Macroscopic ordering of liquid-crystalline polymers with discotic mesogens. Macromolecules, 22, 1960-1963 (1989).

DOI: $10.1021 / \mathrm{ma} 00194 \mathrm{a} 073$

[22] Kumar S.: Triphenylene-based discotic liquid crystal dimers, oligomers and polymers. Liquid Crystals, 32, 1089-1113 (2005).

DOI: 10.1080/02678290500117415

[23] Ganicz T., Makowski T., Stanczyk W. A., Tracz A.: Side chain polysiloxanes with phthalocyanine moieties. Express Polymer Letters, 6, 373-382 (2012). DOI: $10.3144 /$ expresspolymlett.2012.40

[24] Ganicz T., Stańczyk W.: Side-chain liquid crystal polymers (SCLCP): Methods and materials. An overview. Materials, 2, 95-128 (2009).

DOI: $10.3390 / \mathrm{Ma} 2010095$

[25] Armarego W. L. F., Chai C.: Purification of laboratory chemicals. Butterworth-Heinemann, Oxford (2012).

[26] Xing C., Lam J. W. Y., Zhao K., Tang B. Z.: Synthesis and liquid crystalline properties of poly(1-alkyne)s carrying triphenylene discogens. Journal of Polymer Science Part A: Polymer Chemistry, 46, 2960-2974 (2008).

DOI: $10.1002 /$ pola.22631

[27] Marciniec B., Gulinski J., Urbaniak W., Kornetka Z. W.: Comprehensive handbook on hydrosilylation. Pergamon Press, Oxford (1992).

[28] Marciniec B.: Hydrosilylation. Springer, Heidelberg (2009).

[29] Trzaska J., Galewski Z.: Liquid-crystalline properties of 4-alkyl-, 4-alkyloxy and 4-halogene-4'-hydroxyazobenzene alkyloates. Opto-Electronics Review, 17, 129139 (2009). DOI: $\underline{10.2478 / \mathrm{s} 11772-008-0071-7}$
[30] Praefcke K., Kohne B., Singer D.: Hexaalkynyltriphenylene: A new type of nematic-discotic hydrocarbon. Angewandte Chemie International Edition, 29, 177179 (1990). DOI: $10.1002 /$ anie. 199001771

[31] Zamir S., Spielberg N., Zimmermann H., Poupko R., Luz Z.: On the solid polymorphs of the discotic mesogen hexa-octanoyloxytriphenylene. Liquid Crystals, 18, 781-786 (1995).

DOI: $10.1080 / 02678299508036690$

[32] Hird M.: Textures of liquid crystals. Angewandte Chemie, 115, 5969-5970 (2003).

DOI: 10.1002/ange.200385054

[33] Cheda J. A. R., García M. V., Redondo M. I., Gargani S., Ferloni P.: Short chain copper(II) $n$-alkanoate liquid crystals. Liquid Crystals, 31, 1-14 (2004). DOI: $10.1080 / 02678290310001628500$

[34] Pisula W., Kastler M., El Hamaoui B., García-Gutiérrez M-C., Davies R. J., Riekel C., Müllen K.: Dendritic morphology in homeotropically aligned discotic films. ChemPhysChem, 8, 1025-1028 (2007). DOI: $10.1002 /$ cphc. 200600787

[35] Schweicher G., Gbabode G., Quist F., Debever O., Dumont N., Sergeyev S., Geerts Y. H.: Homeotropic and planar alignment of discotic liquid crystals: The role of the columnar mesophase. Chemistry of Materials, 21, 5867-5874 (2009). DOI: $10.1021 / \mathrm{cm} 902634 \mathrm{r}$

[36] Thiebaut O., Bock H., Grelet E.: Face-on oriented bilayer of two discotic columnar liquid crystals for organic donor-acceptor heterojunction. Journal of the American Chemical Society, 132, 6886-6887 (2010). DOI: $10.1021 /$ ja1012596

[37] Verploegen E., Zhang T., Murlo N., Hammond P. T.: Influence of variations in liquid-crystalline content upon the self-assembly behavior of siloxane-based block copolymers. Soft Matter, 4, 1279-1287 (2008). DOI: 10.1039/B800212F

[38] Thünemann A. F., Ruppelt D., Burger C., Müllen K.: Long-range ordered columns of a hexabenzo[bc,ef, $h i$, $k l, n o, q r]$ coronene-polysiloxane complex: Towards molecular nanowires. Journal of Materials Chemistry, 10, 1325-1329 (2000). DOI: $10.1039 / \mathrm{A} 909010 \mathrm{~J}$

[39] Pisula W., Feng X., Müllen K.: Tuning the columnar organization of discotic polycyclic aromatic hydrocarbons. Advanced Materials, 22, 3634-3649 (2010). DOI: $10.1002 / \mathrm{adma} .201000585$ 